\title{
Bird Behaviour on and Entanglement in Invasive Burdock (Arctium spp.) Plants in Winnipeg, Manitoba
}

\author{
TODD J. UndERWOOD ${ }^{1}$ and ROBYN M. UNDERWOOD
}

Department of Biology, Kutztown University, Kutztown, Pennsylvania 19530 USA

${ }^{1}$ Corresponding author; email: underwoo@kutztown.edu

Underwood, Todd J., and Robyn M. Underwood. 2013. Bird behaviour on and entanglement in invasive burdock (Arctium spp.) plants in Winnipeg, Manitoba. Canadian Field-Naturalist 127(2): 164-174.

Burdocks (Arctium spp.) are invasive plants native to Eurasia. They produce their seeds within large burrs that adhere to vertebrates for seed dispersal, i.e., epizoochory. Small animals may become entangled in these burrs and die. Through active searches of natural areas in Winnipeg, Manitoba, from 2000 to 2005, we documented 29 songbirds entangled in burdock burrs and recorded observations of bird behaviour on burdock plants. We analyzed trends among birds found entangled by taxon, sex, age, migratory status, and season, and we compared them to observations of bird activity on burdock. Thirteen species of birds were found entangled. Most birds found entangled (62\%) were warblers (Parulidae), but there were also species from five other families $(<15 \%$ per family). There was no significant difference in the distribution of birds found entangled by sex or age. A significant proportion of birds found entangled were migrants, and the average number of birds found entangled per search visit differed significantly by season, with most birds found entangled in fall. By comparison, we recorded 34 species of birds ( $n=178$ observations) active on burdock plants. Warblers (38\%) and sparrows (Emberizidae) $(24 \%)$ were the most active, followed by small numbers of birds from eight other families ( $<9 \%$ per family). Species that were observed actively foraging on burdocks more often became entangled than those species observed only perching on burdocks. Species found entangled had a significantly lower body mass than species that were not found entangled but were active on burdocks. Overall, we suggest that small-bodied fall migrants that forage on burdock plants are most at risk of becoming entangled.

Key Words: burdock; Arctium; Downy Woodpecker; Picoides pubescens; Yellow-bellied Flycatcher; Empidonax flaviventris; Least Flycatcher; Empidonax minimus; Blue-headed Vireo; Vireo solitarius; Red-eyed Vireo; Vireo olivaceus; Blackcapped Chickadee; Poecile atricapillus; Golden-crowned Kinglet; Regulus satrapa; Ruby-crowned Kinglet; Regulus calendula; Tennessee Warbler; Oreothlypis peregrina; Orange-crowned Warbler; Oreothlypis celata; Nashville Warbler; Oreothlypis ruficapilla; Common Yellowthroat; Geothlypis trichas; Magnolia Warbler; Setophaga magnolia; Yellowrumped Warbler; Setophaga coronata; American Goldfinch; Spinus tristis; entanglement; accidental mortality; foraging; migration; alien plants; Manitoba

Birds are victims of several types of accidental mortality (Erickson et al. 2005). One of the more unusual causes of death is entanglement in plants (Hager et al. 2009). The types of entanglements involved and plants include becoming stuck within or speared on the branches of trees or shrubs (Lloyd 1923; Sherick 1966), entwined by the blades of sedges (Bond 1960), impaled by thorns or cactus spines (Delareuelee 1973; Shackelford and Shackelford 2001), caught in the inflorescences or seed heads of grasses (Powers et al. 1981; Rodríguez et al. 2009), and tangled in the burrs of herbaceous plants (Craves 1998; Underwood and Underwood 2013).

In North America, the most numerous entanglements reported in plants are of birds in burdocks (Arctium spp.), invasive plants native to Eurasia (McNicholl 1988, 1994; Catling 2006; Hager et al. 2009). The large hooked burrs of burdock plants are very effective at epizoochory, i.e., adhering to the external surface of animals for seed dispersal (Kulbaba et al. 2009), but they also trap small birds and other animals (McNicholl 1988).

Across North America, more than 90 birds of at least 15 species have been found entangled in burdock burrs (McNicholl 1994; Hinam et al. 2004; Catling 2006).
Most of these records represent anecdotal reports of one or a few birds found entangled in a single area. In a noteworthy exception, Hinam et al. (2004) summarized 16 birds found entangled and reported a preponderance of migrants among all birds found entangled and a preponderance of juveniles among Ruby-throated Hummingbirds (Archilochus colubris) found entangled. The lack of other studies with large samples of birds found entangled has limited the availability of descriptive data from which to identify the attributes of birds that may increase the risk of entanglement.

Relatively little is known about risk factors for entanglement, especially what makes burdocks attractive to birds and leads to their becoming entangled. Several authors have speculated on the potential sources of attraction of burdock plants or the reasons for birds becoming entangled in burrs. These include seeking nectar from flowers (McAlpine 1976; Hinam et al. 2004), probing burrs for seeds (Bowdish 1906; Terres 1980) or insects (Needham 1909), perching on burrs (Stegeman 1953; Nealen and Nealen 2000), and a combination of perching and foraging on burdock plants (Stensaas 1989; Underwood and Underwood 2001). Alternatively, other events or activities may force birds to come into accidental contact with burrs, such as gusts of wind 
(Herzberg and Juhola 1986; McNicholl 1988), aggressive interactions between conspecifics (Hinam et al. 2004), or chasing insect prey (Hager et al. 2009). However, there has been no direct study of the sources of attraction to burdocks and the reasons for entanglement.

In this five-year study, we searched natural areas in Winnipeg, Manitoba, for birds entangled in burdocks, and we recorded detailed behavioural observations of bird activity on burdock plants. Our first objective was to analyze trends by taxon, sex, age, migratory status, and time of year among the large number of birds found entangled in order to identify patterns that may influence the probability of entanglement. Our second objective was to compare records of birds found entangled to observations of bird activity on burdocks to identify behaviours that influence the risk of entanglement, to identify the potential attraction to burdock plants, and to examine the risk of entanglement by body mass.

\section{Methods}

\section{Data collection}

From September 2000 through May 2005, we opportunistically searched natural areas for birds entangled in burdocks in the southern part of the city of Winnipeg, Manitoba $\left(49^{\circ} 48^{\prime} \mathrm{N}, 97^{\circ} 8^{\prime} \mathrm{W}\right)$. We visited these areas to conduct bird and natural history observations as our schedules and the weather allowed. A typical visit lasted approximately one hour and consisted of walking a loop through the area while observing live birds and scanning burdock patches we passed for entangled birds or bird activity. Over five years, we averaged $73.6(\mathrm{SD} 30.9, \mathrm{n}=368)$ visits per year to natural areas. In addition, one entangled bird was brought to us by a colleague.

Natural areas searched included King's Park (37 ha), La Barriere Park (84 ha), Maple Grove Park (62 ha), and the agricultural research area on the Fort Garry Campus of the University of Manitoba (43 ha). Most areas are along the Red River, except La Barriere Park, which is along the La Salle River, a tributary of the Red River. The riparian forest habitat of these areas had some trails through the forest and open mowed lawn. Burdocks were abundant in each area, with many large patches (e.g., $\geq 3 \times 3 \mathrm{~m}$ ) as well as isolated individual plants present along edges, trails, and openings in woodlands.

We believe that most of the burdock plants in these areas were Great Burdock (Arctium lappa) and Woolly Burdock (A. tomentosum), based on the large height of the plants $(1-3 \mathrm{~m})$, the length of the peduncles, and the wide diameter $(>2 \mathrm{~cm})$ of the burrs (Scoggan 1957). We did not identify the species of burdock plant in which each bird was found entangled because of the difficulty in distinguishing the species without fresh flowers. Because of this challenge, we incorrectly identified these plants as Common Burdock (A. minus) in a previous paper (Underwood and Underwood 2001).
For each entangled bird found dead, we described its condition and deposited the specimen in the Manitoba Museum, Winnipeg, Manitoba (MM) (acronyms follow the Registry of Biological Repositories, http://www.bio repositories.org), or the University of Manitoba Zoology Museum (UMBZM), also in Winnipeg. The University of Manitoba Zoology Museum held appropriate salvage permits (Appendix 1). Freshly killed birds had their plumage in good condition, eyes still intact, and no odour of decay. Birds beginning to decompose had one or more of the following: exposed flesh, desiccated or sunken eyes, and an odour of decay. Birds that were mostly decomposed consisted of mainly feathers and bones.

We identified each bird by species, sex, and age using plumage characters and measurements (Pyle 1997). We attempted to release entangled birds found alive, and we recorded the species, sex, and age where possible. One bird that died after extraction from the burrs was sexed by dissection and prepared as a museum skin (UMBZM 902) (Appendix 1).

We also recorded observations of bird activity that involved contact with burdock plants to assess behaviours that may influence the risk of entanglement. Because bird activity on burdocks was infrequent and unpredictable, we used ad libitum sampling to document all behaviours of individuals in our notebooks over the period birds were visible (typically a few seconds to a few minutes). This method of behavioural sampling is appropriate for rare and unpredictable events (Dawkins 2007). From our detailed field notes, we categorized behaviours by species and whether birds were observed perching or foraging on particular parts of burdock plants.

\section{Analyses}

We summarized records of birds found entangled by taxon, sex, age, migratory status, and season. Data from the fall of 2000, previously described but not analyzed (Underwood and Underwood 2001), were also included. We compared the birds' sex, age, and migratory status using $\chi^{2}$ tests; when expected values were below five, we used Fisher's exact tests. To analyze the timing of entanglements, we categorized timing by season as defined by the Checklist of the Birds of Manitoba (Manitoba Avian Research Committee 2009): spring (March-May), summer (June-August), fall (September-November), and winter (December-February).

Because our search effort varied by season (proportion of visits/season $=34.2 \%$ in spring, $23.4 \%$ in summer, $30.2 \%$ in fall, $12.2 \%$ in winter; $n=368$ ), we standardized seasonal data by the average number of birds found entangled per visit. Only birds we found alive, freshly dead, or just beginning to decompose ( $n=18$ birds) were included because they were likely to have been caught within three weeks of discovery and could be confidently assigned to a season. The bird brought to us by a colleague was excluded from this analysis. Because these data were not normally distributed, we 

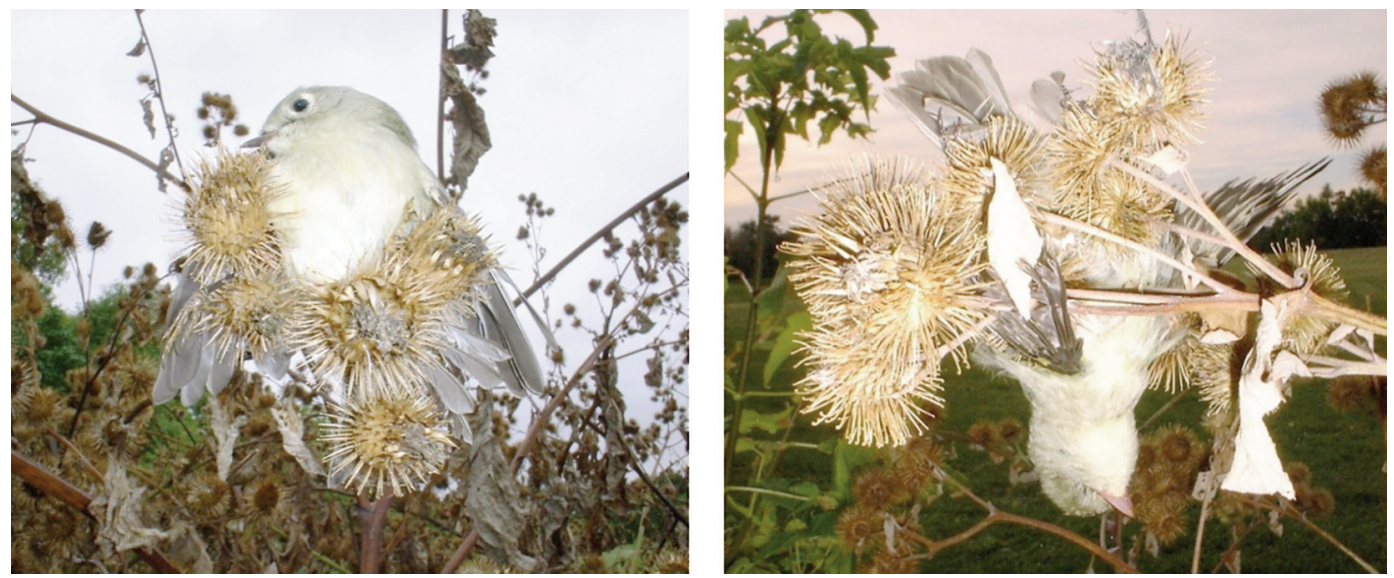

FIGURE 1. Birds found entangled in burdock (Arctium spp.) burrs in Winnipeg, Manitoba: Ruby-crowned Kinglet (Regulus calendula) (left) found alive on 21 September 2001 and Yellow-bellied Flycatcher (Empidonax flaviventris) found dead on 13 September 2001.

used a Kruskal-Wallis test to analyze the timing of entanglements.

We visually compared the frequency of entanglements to that of bird activity on burdock by family. We compared the number of species that were found entangled to the number not found entangled by their type of activity on burdocks. A Fisher's exact test was used for this analysis because expected values were below five. We compared the body mass of species found entangled to the body mass of species not found entangled but recorded as being active on burdocks. Because these data were not normally distributed, we used a Mann-Whitney $U$ test. The average mass of each species was obtained from the Birds of North America species accounts.

\section{Results}

We discovered 28 birds entangled in burdocks, for an average of 0.08 birds found/visit (SE $0.02, n=368$ visits) to a natural area. Overall, we documented a total of 29 birds from 13 species entangled in burdocks (Figure 1, Table 1). The birds most commonly found entangled were New World warblers (Parulidae), but small numbers of species in five other families were also found (Table 1, Figure 2). Only two of these birds were found alive: a Ruby-crowned Kinglet (see Table 1 for scientific names of birds) (Figure 1) was extracted and flew away upon release and a fledgling Least Flycatcher that was in poor condition died after we brought it to a wildlife rehabilitation centre. We also

TABLE 1. The number of birds found entangled in burdocks (Arctium spp.) in Winnipeg, Manitoba, from 2000 to 2005, by species, with their migratory status and average body mass.

\begin{tabular}{lccl}
\hline \hline & $\begin{array}{c}\text { No. of } \\
\text { birds found } \\
\text { entangled }\end{array}$ & $\begin{array}{c}\text { Migratory } \\
\text { status }^{1}\end{array}$ & Body mass (g)and source ${ }^{2}$ \\
Species and family & 1 & migrant & 11.3 (Gross and Lowther 2011) \\
Yellow-bellied Flycatcher flaviventris) (Tyrannidae) & 3 & breeder & 10.5 (Tarof and Briskie 2008) \\
Least Flycatcher (Empidonax minimus) (Tyrannidae) & 1 & migrant & 15.4 (James 1998) \\
Blue-headed Vireo (Vireo solitarius) (Vireonidae) & 1 & breeder & 20.3 (Cimprich et al. 2000) \\
Red-eyed Vireo (Vireo olivaceus) (Vireonidae) & 1 & breeder & 12.2 (Foote et al. 2010) \\
Black-capped Chickadee (Poecile atricapillus) (Paridae) & 1 & migrant & 6.2 (Swanson et al. 2012) \\
Golden-crowned Kinglet (Regulus satrapa) (Parulidae) & 2 & migrant & 6.7 (Swanson et al. 2008) \\
Ruby-crowned Kinglet (Regulus calendula) (Parulidae) & 7 & migrant & 9.6 (Rimmer and Mcfarland 1998) \\
Tennessee Warbler (Oreothlypis peregrina) (Parulidae) & migrant & 9.4 (Gilbert et al. 2010) \\
Orange-crowned Warbler (Oreothlypis celata) (Parulidae) & 3 & migrant & 8.8 (Lowther and Williams 2011) \\
Nashville Warbler (Oreothlypis ruficapilla) (Parulidae) & 5 & migrant & 8.5 (Dunn and Hall 2010) \\
Magnolia Warbler (Setophaga magnolia) (Parulidae) & 2 & migrant & 12.6 (Hunt and Flaspohler 1998) \\
Yellow-rumped Warbler (Setophaga coronata) (Parulidae) & 1 & breeder & 11.4 (McGraw and Middleton 2009) \\
American Goldfinch (Spinus tristis) (Fringillidae) & 1 & & \\
Total no. of birds found entangled & 29 & & \\
\hline
\end{tabular}

${ }^{1}$ Migratory or breeding status of birds in natural areas where found entangled (Taylor et al. 2003; TJU and RMU, personal observations).

${ }^{2}$ Represents the mass of both sexes or, when reported separately by sex, the average mass of both sexes. 


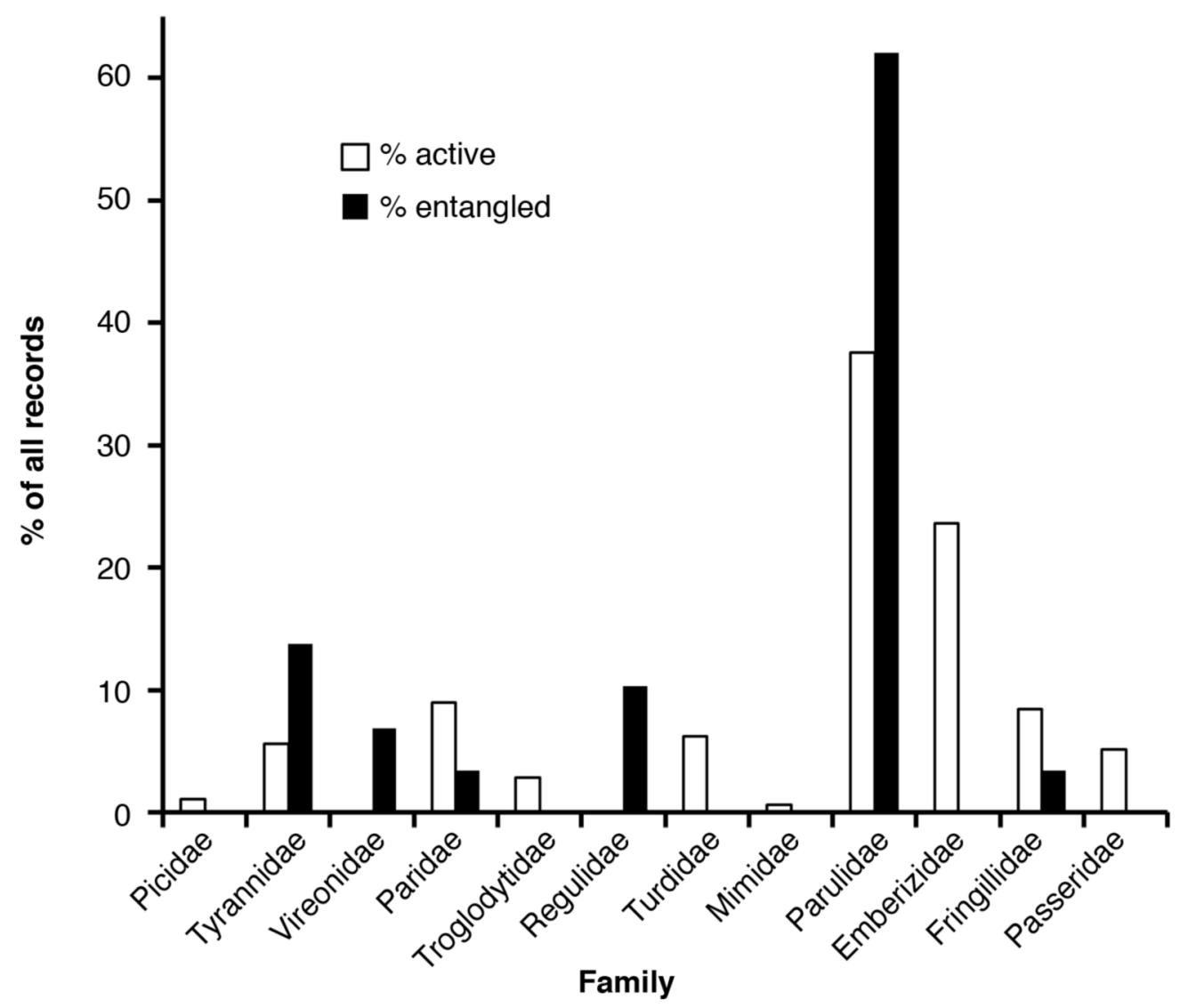

FIGURE 2. A comparison of the relative frequency of birds found entangled in burdocks (Arctium spp.) $(n=29)$ with birds observed active on burdocks ( $n=178)$, by family, in Winnipeg, Manitoba, from 2000 to 2005 .

found a few feathers from unknown species attached to burrs on three separate dates (Appendix 1). The colour patterns on two sets of feathers suggest they were possibly from sparrows, whereas the third set of feathers could have been from any one of several potential species (Appendix 1).

Most specimens (18) could not be sexed and 6 could not be aged due to their condition. The distribution of birds found entangled that could be sexed ( 3 males and 8 females) (Appendix 1) did not differ significantly by $\operatorname{sex}\left(\chi^{2}=2.27, P=0.13\right)$, and the distribution of birds found entangled whose age could be determined (12 after-hatch year and 11 hatch year) (Appendix 1) did not differ by age $\left(\chi^{2}=0.04, P=0.84\right)$. Migrants were found entangled significantly more often than birds known to breed in the area (23 migrants and 6 breeders) (Table 1) $\left(\chi^{2}=9.97, P<0.01\right)$. The average number of birds found entangled per visit differed significantly by season $(H=12.25, \mathrm{df}=3, P<0.01)(\bar{x}=0.02 /$ visit, SE $0.01, n=126$ visits in spring; $\bar{x}=0.02 /$ visit, SE $0.02, n=86$ visits in summer; $\bar{x}=0.13 /$ visit, $\mathrm{SE}$ $0.05, n=111$ visits in fall; $\bar{x}=0.00 /$ visit, $n=45$ visits in winter). Entangled birds were discovered most frequently during fall (14 of 18 birds we found entangled that were assigned to a season) (Appendix 1).

We recorded 34 species of birds active on burdocks ( $n=178$ observations). Warblers and sparrows (Emberizidae) were the most frequent groups of birds recorded as being active on burdocks, followed by small numbers of birds from eight other families (Figure 2). Other than warblers, the frequency of activity on burdocks poorly matched the frequency of birds found entangled at the family level (Figure 2). Despite being found entangled in burdocks, no birds in the families Vireonidae and Regulidae were recorded as being active on burdocks. Of all bird behaviours on burdocks, $79 \%$ involved perching and $21 \%$ involved foraging. Observations of perching only involved perching on burdock stems, never on actual burrs.

We found that species that actively foraged on burdocks were found entangled significantly more often than species that only perched on burdocks (Fisher's exact test, $P<0.01$ ) (Figure 3 ). Birds recorded foraging on burdocks ( $n=37$ observations) were most often war- 
TABLE 2. The number of observations of birds recorded foraging on burdocks (Arctium spp.), by foraging behaviour, in Winnipeg, Manitoba, from 2000 to 2005.

\begin{tabular}{llc}
\hline \hline Foraging behaviour & Species & No. of observations \\
\hline Probing dead leaves & Black-capped Chickadee & 5 \\
& Tennessee Warbler & 1 \\
& Orange-crowned Warbler & 5 \\
& Nashville Warbler & 3 \\
& Common Yellowthroat & 1 \\
Probing burrs & Subtotal & 15 \\
& Black-capped Chickadee & 3 \\
& Orange-crowned Warbler & 1 \\
Pecking at stem & Yellow-rumped Warbler & 3 \\
& Subtotal & 7 \\
Probing burr and green leaves & Downy Woodpecker & 2 \\
& Subtotal & 2 \\
General ${ }^{1}$ & Black-capped Chickadee & 1 \\
& Subtotal & 1 \\
Subtotal & Tennessee Warbler & 1 \\
Total & Orange-crowned Warbler & 6 \\
\hline \hline
\end{tabular}

${ }^{1}$ No specific foraging location or activity was noted for these observations.

blers $(70.3 \%)$, but also included chickadees (Paridae) $(24.3 \%)$ and woodpeckers (Picidae) $(5.4 \%)$ (Table 2). Of the specific foraging behaviours noted $(n=25)$, probing dead leaves $(60 \%)$ was the most commonly recorded (Table 2). We also found that species that were active on burdocks, but were not found entangled, had significantly greater body mass than species found entangled $(U=57.5, P<0.01 ; \bar{x}=23.3 \mathrm{~g}, \mathrm{SE}$ $2.9, n=26$ vs. $\bar{x}=11.0 \mathrm{~g}$, SE $1.0, n=13)$.

\section{Discussion}

We found 13 species of birds entangled in burdocks. Of these birds, 3 species_-Yellow-bellied Flycatcher, Red-eyed Vireo, and Orange-crowned Warbler-have not been previously recorded entangled in burdocks (McNicholl 1994; Catling 2006; Hager et al. 2009). The 29 birds we found in the same general area across five years represent one of the largest sets of burdock entanglements from a single area.

Only a few published reports have identified large numbers of birds found entangled. Needham (1909) reported "scores" of Golden-crowned Kinglets entangled in burdocks in Illinois on a single day, but did not provide an actual count of these birds. However, scores, i.e., multiples of 20, implies at least 40 birds. More recently, Iron (2002) discovered 11 kinglets, mostly Golden-crowned Kinglets, in one year in a single park in Ontario, and Hinam et al. (2004) summarized 16 birds, mostly Ruby-throated Hummingbirds, over 21 years in Delta Marsh, Manitoba.

We suspect that the large number of birds found entangled in this study was a consequence of the abundance of burdocks in the areas we searched and the importance of these areas for migration. Most of the birds

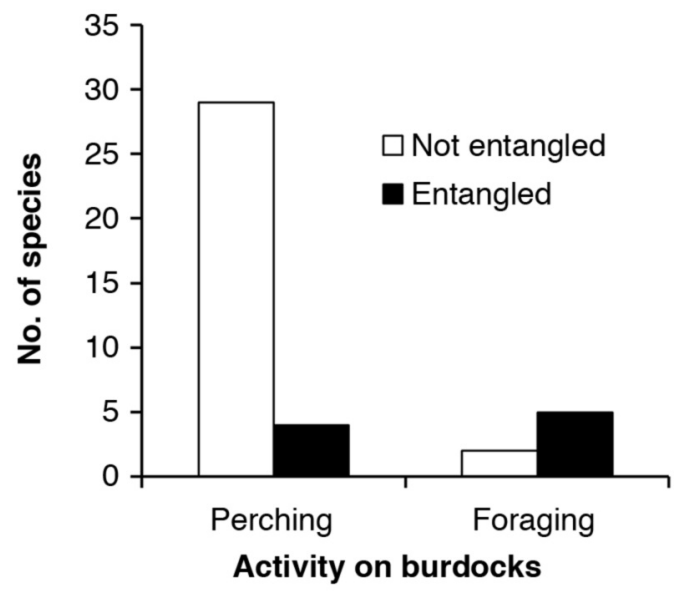

FIGURE 3. A comparison of the number of species found entangled in burdocks (Arctium spp.) with the number of species not recorded entangled in burdocks, by the type of activity recorded on burdocks in Winnipeg, Manitoba, from 2000 to 2005.

found entangled were among large patches $(\geq 3 \times 3 \mathrm{~m})$ of burdocks rather than in isolated plants. The Red River valley is an important north-south migration corridor for raptors, waterfowl, and songbirds (Taylor et al. 2003). The riparian habitat along the river constitutes important stopover habitat for migratory birds amongst the farmland and urban/suburban areas that surround the Red River in southern Manitoba. For example, in King's Park, we documented over 150 species of birds, mostly migrants, utilizing the park (20002005, TJU and RMU, personal observations). Bird en- 
tanglements at Delta Marsh, Manitoba, have been similarly linked to the importance of riparian habitat to migratory birds (Hinam et al. 2004).

There was no difference in the numbers of birds found entangled by sex. The lack of a sex difference is not unexpected, because there is no strong basis to suggest a sex-biased risk of entanglement, unless aggressive interactions between males strongly influence entanglement (e.g., Hinam et al. 2004). For example, there is no overall sex bias in the number of birds killed through other types of accidental mortality, such as collisions with towers or windows (Crawford 1978; Klem 1989).

Although we found no significant difference by age, this result may be an artifact of sample size. Age is more likely to be important because lack of experience may increase a bird's risk of becoming entangled in burdocks (Kubisz 1989). Furthermore, young birds may be more susceptible to accidents because there are more of them in the population in the fall (Klem 1989; Crawford and Engstrom 2001). The two other studies with a large number of one species reported being entangled in burdocks found more juveniles than adults among Golden-crowned Kinglets (Needham 1909) and Rubythroated Hummingbirds (Hinam et al. 2004). The small sample sizes of each species necessitated that these data be pooled for analysis, and we suspect that this may have influenced the lack of significant differences in our data.

Most birds found entangled in this study were migrant songbirds that were captured during fall. Breeding birds made up only a small portion of entanglements, and few birds found entangled were discovered in summer or winter. A similar trend for migrants was noted at Delta Marsh, Manitoba (Hinam et al. 2004). Migrants comprise a large portion of birds killed through accidental collisions with towers (Crawford and Engstrom 2001) and windows (Klem 1989), although collisions with windows are also responsible for the deaths of many winter residents attracted by bird feeders (Klem 2010). A similar larger number of birds killed at towers during fall migration has been suggested to be due in part to more birds migrating at this time (i.e., offspring from the breeding season and before any migration or winter mortality) (Crawford and Engstrom 2001).

The higher average of entangled birds discovered in fall than in spring was likely due to this discrepancy in the size of the migrating population but also due to burdock phenology. In southern Manitoba, burdock plants flower from mid-July into September (Kenkel and Graham 1994) and die thereafter. The fresh green flowers or burrs are just as adherent as dried burrs (TJU, personal observation) and can entrap birds (e.g., Hinam et al. 2004). By late summer, when fall migration begins, a fresh crop of burrs is available, but over the winter many of these burrs fall off, e.g., $>60 \%$ of Arctium lappa burrs and $>20 \%$ of $A$. minus burrs (Hawthorn and
Hayne 1978), or entire plants may be knocked down. Thus, the environmental risk of entanglement peaks in late summer and fall when songbirds are migrating through southern Manitoba. Migrants may also be at a higher risk of entrapment because they may be less familiar with the surroundings than resident birds.

The frequency of bird activity on burdocks closely matched records of entanglement only for warblers and was a poor match for most other families, especially sparrows (Figure 2). This discrepancy is likely explained by the type of activities observed on burdock plants. Species that only perched on burdocks were found entangled less often than species that foraged on burdocks. We recorded high sparrow activity on burdocks, but all of the sparrows we observed on burdocks were perching. Sparrows typically forage on the ground and use perches above ground to sing or to pause after being flushed from the ground (Rising 1996). Thus, simple perching on burdock stems does not appear to be a risky behaviour, perhaps because it is only momentary and birds do not come into contact with burrs.

By comparison, Downy Woodpeckers (Picoides pubescens) and Common Yellowthroats (Geothlypis trichas) were the only two of seven species that we recorded foraging on burdocks that were never found entangled. The Downy Woodpecker is large-bodied (28 g) (Jackson and Ouellet 2002), and it was observed only perched on and pecking at the main flowering stalk of burdocks, a behaviour that may present a risk more similar to perching than foraging. Most observations of foraging involved birds moving among a patch of plants and stopping to probe inside dead leaves or to probe inside burrs. Thus, these movements among the burdock plants and deliberate contact with burrs appear to strongly increase a bird's risk of becoming entangled.

We suspect that the tendency of songbirds to forage among burdock plants is influenced by weather. A large number of entangled birds (12) was discovered between 19 September and 4 October 2003 (Appendix 1), during a period of cooler-than-average weather. This period in 2003 had the coldest average daily temperature $\left(6.6^{\circ} \mathrm{C}\right)$ in Winnipeg compared to the same period in any of the ten years surrounding this study (19962005 , overall $\bar{x}=9.5^{\circ} \mathrm{C}$, SE $0.38, n=10$ ) (Environment Canada 2013*). Weather has a strong impact on foraging behaviour in some birds. For example, resident woodland songbirds, such as Black-capped Chickadees and Tufted Titmice (Baeolophus bicolor), respond to lower temperatures and higher wind speeds in winter by reducing their foraging height from the canopy to the shrub layer and altering their foraging substrate (Grubb 1975). Furthermore, unseasonably cool or inclement weather during migration in Manitoba has been linked to changes in the foraging behaviour of insectivorous warblers, which switch from feeding in the canopy to feeding on or near the ground (Sealy 1988, 1989). Inclement weather during migration could 
force birds that typically forage in the canopy of the forest, such as warblers and vireos, to move into the shrub layer, where burdocks were abundant in certain locations in the study areas.

Most birds in the study areas appear to be attracted to burdock plants by arthropod prey. Birds found entangled were mostly insectivores (i.e., flycatchers, vireos, kinglets, and warblers), although some also eat fruit during migration (Hunt and Flaspohler 1998; James 1998; Rimmer and Mcfarland 1998; Cimprich et al. 2000; Swanson et al. 2008; Tarof and Briskie 2008; Dunn and Hall 2010; Gilbert et al. 2010; Gross and Lowther 2011; Lowther and Williams 2011; Swanson et al. 2012). Only two of the bird species we found entangled, Black-capped Chickadee and American Goldfinch, regularly eat seeds (Martin et al. 1961) and might be attracted to burrs for their seeds.

Burdock plants provide habitat for arthropod prey in their dead dried leaves and their burrs. In both temperate and tropical forests, dried leaves contain a larger number and higher biomass of arthropods than live green leaves (Greenberg 1987). Foraging in dead leaves is a specialized niche used mainly during the nonbreeding season by several Neotropical resident and migrant songbirds (Remsen and Parker 1984; Greenberg 1987; Remsen et al. 1989). Four species of Neotropical migrant warblers in the former genus Vermivora, including Orange-crowned Warblers, have been reported to specialize in this foraging behaviour in winter. Some temperate residents may also regularly forage in dead leaves (Remsen et al. 1989).

We observed four different species of warblers and Black-capped Chickadees probing dead leaves (Table 2 ), but rarely observed them capturing prey because we were not close enough to the birds. On 16 September 2001, we observed an Orange-crowned Warbler capture a caterpillar from within a dead burdock leaf. Although arthropod abundance in dead burdock leaves has not been quantified, our observations suggest that prey are available and birds are attracted to burdocks to forage for arthropods.

Burdock burrs also house potential arthropod prey for birds. Moths, bees, grasshoppers, and other insects occasionally become stuck to burrs (Zimmer and Kantrud 1987; McIlveen and Gaunt 2009; TJU, personal observation) and might be prey for birds when they are still fresh. A more important and regular source of prey is the larvae of the Burdock Seedhead Moth (Metzneria lappella). These larvae are seed predators that feed on developing burdock seeds inside the burrs (Gross et al. 1980). Metzneria lappella larvae may be quite abundant and have been found to occupy 34\% of Arctium lappa burrs, with an average of 0.6 larvae per burr, and M. lappella larvae have been found to occupy 80-99\% of $A$. minus burrs, with an average of 1.4 to 4.0 larvae per burr (Hawthorn and Hayne 1978).
Needham (1909) was the first to point out that $M$. lappella larvae likely attract birds to the burrs. His suggestion has often been repeated in the literature but without any confirmation that birds are capturing insect larvae from burrs. On 3 September 2003, we observed a Yellow-rumped Warbler take a small insect larva, possibly $M$. lappella, from a burr, providing the first real evidence that birds are attracted to burrs to forage on insects. First-instar $M$. lappella larvae appear in burrs by late July, mature in fall, and overwinter as larvae in burrs (Hawthorn and Hayne 1978). Thus, the availability of insects on burrs remains high during fall, providing another link to the greater number of birds found entangled in the fall.

The presence of arthropod prey on burdock leaves and in burrs might not be considered an attractant for Empidonax flycatchers because of their use of hawking manoeuvres to capture aerial prey. However, Empidonax flycatchers, especially Least Flycatchers, regularly glean insects from vegetation (Murphy 1989). Least Flycatchers are also known to forage lower in the canopy and to glean prey from vegetation more often during inclement weather (Tarof and Briskie 2008). These foraging behaviours suggest that Empidonax flycatchers might be apt to forage for arthropod prey on burdock plants, particularly during inclement weather. Alternatively, flycatchers might come into contact with burdock burrs accidentally while actively pursuing aerial insects (Hager et al. 2009) or if they use burdocks as a perch from which to hawk insects.

In addition to bird activity on burdocks, body mass likely influences the probability of becoming entangled. Species of birds active on burdocks, but never found entangled, had a greater body mass than species found entangled. The species found entangled in our study ranged from 6 to $20 \mathrm{~g}$ in body mass, and all but two species (Blue-headed Vireo and Red-eyed Vireo) weighed less than $13 \mathrm{~g}$ (Table 1). Unfortunately, our specimens of only feathers stuck to burrs did not have any colours or patterns distinct enough to allow a positive identification to be made.

The presence of a few body feathers suggests that some birds are occasionally able to escape becoming fatally entangled. Alternatively, feathers found on burrs may suggest these birds were taken by scavengers, as is known to occur with the carcasses from other types of accidental mortality (Longcore et al. 2012). However, based on the extent to which most birds were entangled in burrs (Figure 1) (see Underwood and Underwood 2001), we would expect more body parts or blood to be left behind if birds were scavenged.

The identity of species capable of extracting themselves from burrs might help identify the size limits of birds at risk of becoming entangled. Other reports of birds found entangled in burdocks (summarized in McNicholl 1994; Catling 2006; Hager et al. 2009) re- 
flect a size range of small birds - Ruby-throated Hummingbirds to Blue-headed Vireos - similar to the birds in this study. These results suggest that birds larger than $20 \mathrm{~g}$ are less likely to become entangled in burdocks than smaller birds.

We found a relatively large number of birds entangled in burdocks over five years in natural areas in Winnipeg, Manitoba. The overall number of birds that were found entangled suggests that entanglement in burdocks may not be as rare as indicated by previous anecdotal reports. However, the relatively low number of birds found entangled per visit also suggests that burdocks may not constitute a major source of mortality on a regional scale, compared to accidental collisions with anthropogenic structures (e.g., Erickson et al. 2005).

The concentration of birds found entangled in areas searched was likely due to the abundance of burdock plants and the importance of these riparian areas as stopover habitat to songbird migrants. Thus, burdock mortality may be important only in certain local areas. Birds found entangled were mostly insectivorous migrants that had become entangled during fall, but there were no trends by age or sex.

Our observations showed that birds are attracted to burdock plants by arthropod prey among dead leaves and burrs. Foraging activity on burdocks combined with small body size appears to greatly increase a bird's risk of fatal entanglement, whereas perching is a less risky activity. We suggest that inclement weather may influence entanglements by forcing insectivores out of the canopy to forage closer to the ground and amongst burdock plants. Future studies are needed to understand the importance of burdock-related bird mortality on a broader geographic scale and to examine how foraging behaviour around burdocks relates to weather conditions.

\section{Acknowledgements}

We thank Heidi den Haan and Spencer Sealy for assistance with aging and sexing the bird specimens, Leonard Hutchison for collecting one of the Tennessee Warbler specimens, and Janis Klapecki for providing information about specimens deposited in the Manitoba Museum. We also thank Spencer Sealy and two anonymous reviewers for comments on the manuscript.

\section{Documents Cited (marked * in text)}

Environment Canada. 2013. Historical Climate Data. Government of Canada, Ottawa, Ontario. http://climate.weather .gc.ca/index_e.html\#access. (Accessed July 2013)

\section{Literature Cited}

Bond, R. M. 1960. Bird trapped by sedge. Condor 62: 294295.

Bowdish, B. S. 1906. Bird tragedies. Bird-Lore 8: 208.

Catling, P. M. 2006. Effects of invasive alien plants on birds: some examples from North America. Biodiversity 6(4): 30-39.
Cimprich, D. A., F. R. Moore, and M. P. Guilfoyle. 2000. Red-eyed Vireo (Vireo olivaceus). No. 527 in The Birds of North America. Edited by A. Poole. Cornell Lab of Ornithology, Ithaca, New York. http://bna.birds.cornell.edu/bna /species/527. (Accessed October 2012).

Craves, J. A. 1998. Swainson's Thrush caught in enchanter's nightshade. Wilson Bulletin 110: 569-570.

Crawford, R. L. 1978. Autumn bird casualties at a northwest Florida TV tower: 1973-1975. Wilson Bulletin 90: 335345 .

Crawford, R. L., and R. T. Engstrom. 2001. Characteristics of avian mortality at a north Florida television tower: a 29-year study. Journal of Field Ornithology 72: 380-388.

Dawkins, M. S. 2007. Observing Animal Behaviour: Design and Analysis of Quantitative Data. Oxford University Press, Oxford, U.K. 158 pages.

Delareuelee, R. R. 1973. Clark's Nutcracker caught on cholla cactus. Western Birds 4: 61.

Dunn, E., and G. A. Hall. 2010. Magnolia Warbler (Setophaga magnolia). Revised. No. 136 in The Birds of North America. Edited by A. Poole. Cornell Lab of Ornithology, Ithaca, New York. http://bna.birds.cornell.edu/bna/species /136. (Accessed October 2012).

Erickson, W. P., G. D. Johnson, and D. P. Young, Jr. 2005. A summary and comparison of bird mortality from anthropogenic causes with an emphasis on collisions. Pages 1029-1042 in Bird Conservation Implementation and Integration in the Americas. Edited by C. J. Ralph and T. D. Rich. U.S. Department of Agriculture, Forest Service, General Technical Report PSW-GTR-191. Pacific Southwest Research Station, Albany, California.

Foote, J. R., D. J. Mennill, L. M. Ratcliffe, and S. M. Smith. 2010. Black-capped Chickadee (Poecile atricapillus). Revised. No. 39 in The Birds of North America. Edited by A. Poole. Cornell Lab of Ornithology, Ithaca, New York. http: //bna.birds.cornell.edu/bna/species/039. (Accessed October 2012).

Gilbert, W. M., M. K. Sogge, and C. Van Riper III. 2010. Orange-crowned Warbler (Oreothlypis celata). Revised. No. 101 in The Birds of North America. Edited by A. Poole. Cornell Lab of Ornithology, Ithaca, New York. http://bna.birds .cornell.edu/bna/species/101. (Accessed October 2012).

Greenberg, R. 1987. Seasonal foraging specialization in the Worm-eating Warbler. Condor 89: 158-168.

Gross, D. A., and P. E. Lowther. 2011. Yellow-bellied Flycatcher (Empidonax flaviventris). Revised. No. 566 in The Birds of North America. Edited by A. Poole. Cornell Lab of Ornithology, Ithaca, New York. http://bna.birds .cornell.edu/bna/species/566. (Accessed October 2012).

Gross, R. S., P. A. Werner, and W. R. Hawthorn. 1980. The biology of Canadian weeds. 38. Arctium minus (Hill) Bernh. and A. lappa L. Canadian Journal of Plant Science 60: 621-634.

Grubb, T. C., Jr. 1975. Weather-dependent foraging behavior of some birds wintering in a deciduous woodland. Condor 77: 175-182.

Hager, S. B., B. Dziadyk, and K. J. McKay. 2009. Birdplant entanglement: a review and addition of the Least Flycatcher. Wilson Journal of Ornithology 121: 648-651.

Hawthorn, W. R., and P. D. Hayne. 1978. Seed production and predispersal seed predation in the biennial composite species, Arctium minus (Hill) Bernh. and A. lappa L. Oecologia 34: 283-295. 
Herzberg, L., and H. Juhola. 1986. [untitled] Toronto Field Naturalist 384: 25.

Hinam, H. L., S. G. Sealy, and T. J. Underwood. 2004. Ruby-throated Hummingbird, Archilochus colubris, entanglements in burdock, Arctium spp., at Delta Marsh, Manitoba. Canadian Field-Naturalist 118: 85-89.

Hunt, P. D., and D. J. Flaspohler. 1998. Yellow-rumped Warbler (Setophaga coronata). No. 376 in The Birds of North America. Edited by A. Poole. Cornell Lab of Ornithology, Ithaca, New York. http://bna.birds.cornell.edu/bna /species/376. (Accessed October 2012).

Iron, J. 2002. Kinglet killer. OFO News: Newsletter of the Ontario Field Ornithologists 20(2): 8-9.

Jackson, J. A., and H. R. Ouellet. 2002. Downy Woodpecker (Picoides pubescens). No. 613 in The Birds of North America. Edited by A. Poole. Cornell Lab of Ornithology, Ithaca, New York. http://bna.birds.cornell.edu/bna/species/613. (Accessed October 2012).

James, R. D. 1998. Blue-headed Vireo (Vireo solitarius). No. 379 in The Birds of North America. Edited by A. Poole. Cornell Lab of Ornithology, Ithaca, New York. http:// bna.birds.cornell.edu/bna/species/379. (Accessed October 2012).

Kenkel, N. C., and K. Graham. 1994. Population biology and the control of common burdock (Arctium minus (Hill) Berhn.) at the University Field Station, Delta Marsh. University Field Station (Delta Marsh) Annual Report 29: 112116.

Klem, D., Jr. 1989. Bird-window collisions. Wilson Bulletin 101: 606-620.

Klem, D., Jr. 2010. Sheet glass as a principal human-associated avian mortality factor. Pages 276-289 in Avian Ecology and Conservation: A Pennsylvania Focus with National Implications. Edited by S. K. Majumdar, T. L. Master, M. C. Brittingham, R. M. Ross, R. S. Mulvihill, and J. E. Huffman. Pennsylvania Academy of Science, Easton, Pennsylvania. 368 pages.

Kubisz, M. A. 1989. Burdock as a hazard to Golden-crowned Kinglets and other small birds. Ontario Birds 7: 112-114.

Kulbaba, M. W., J. C. Tardif, and R. J. Staniforth. 2009. Morphological and ecological relationships between burrs and furs. American Midland Naturalist 161: 380-391.

Lloyd, H. 1923. Brown Creeper the victim of strange accident. Canadian Field-Naturalist 37: 75.

Longcore, T., C. Rich, P. Mineau, B. MacDonald, D. G. Bert, L. M. Sullivan, E. Mutrie, S. A. Gauthreaux Jr., M. L. Avery, R. L. Crawford, A. M. Manville II, E. R. Travis, and D. Drake. 2012. An estimate of avian mortality at communication towers in the United States and Canada. PLoS ONE 7(4): e34025.

Lowther, P. E., and J. M. Williams. 2011. Nashville Warbler (Oreothlypis ruficapilla). Revised. No. 205 in The Birds of North America. Edited by A. Poole. Cornell Lab of Ornithology, Ithaca, New York. http://bna.birds.cornell.edu/bna /species/205. (Accessed October 2012).

Manitoba Avian Research Committee. 2009. Checklist of the Birds of Manitoba. Nature Manitoba, Winnipeg, Manitoba. 12 pages.

Martin, A. C., H. S. Zim, and A. L. Nelson. 1961. American Wildlife Plants: A Guide to Wildlife Food Habits. Dover Publications, Inc., New York, New York. 500 pages.

McAlpine, D. F. 1976. Additional records of Ruby-throated Hummingbirds trapped on burdocks. New Brunswick Naturalist 7: 41-42.
McGraw, K. J., and A. L. Middleton. 2009. American Goldfinch (Spinus tristis). Revised. No. 80 in The Birds of North America. Edited by A. Poole. Cornell Lab of Ornithology, Ithaca, New York. http://bna.birds.cornell.edu /bna/species/080. (Accessed October 2012).

McIlveen, W. D., and R. Gaunt. 2009. Carolina locust caught by burdock. Ontario Insects 13(2): 22.

McNicholl, M. K. 1988. Bats and birds stuck on burdock. Prairie Naturalist 20: 157-160.

McNicholl, M. K. 1994. Additional records of birds caught on burdock. Ontario Birds 12: 117-119.

Murphy, M. T. 1989. Life history variability in North American breeding tyrant flycatchers: phylogeny, size or ecology? Oikos 54: 3-14.

Nealen, H. J., and P. M. Nealen. 2000. Ruby-throated Hummingbird death by common burdock (Arctium minus). Wilson Bulletin 112: 421-422.

Needham, J. G. 1909. Kinglets captured by burdocks. BirdLore 11: 261-262.

Powers, L. R., D. Gertson, and J. L. Demmer. 1981. A natural hazard to small birds. Murrelet 62: 23-24.

Pyle, P. 1997. Identification Guide to North American Birds. Part I. Slate Creek Press, Bolinas, California. 732 pages.

Remsen, J. V., Jr., and T. A. Parker III. 1984. Arboreal deadleaf-searching birds of the Neotropics. Condor 86: 36-41.

Remsen, J. V., Jr., M. Ellerman, and J. Cole. 1989. Deadleaf-searching by the Orange-crowned Warbler in Louisiana in winter. Wilson Bulletin 101: 645-648.

Rimmer, C. C., and K. P. Mcfarland. 1998. Tennessee Warbler (Oreothlypis peregrina). No. 350 in The Birds of North America. Edited by A. Poole. Cornell Lab of Ornithology, Ithaca, New York. http://bna.birds.cornell.edu/bna/species 1350. (Accessed October 2012).

Rising, J. D. 1996. A Guide to the Identification and Natural History of the Sparrows of the United States and Canada. Academic Press, San Diego, California. 365 pages.

Rodríguez, A., F. Siverio, R. Barone, B. Rodríguez, and J. J. Negro. 2009. An overlooked cost for the velvety plumage of owls: entanglement in adhesive vegetation. Wilson Journal of Ornithology 121: 439-441.

Scoggan, H. J. 1957. Flora of Manitoba. Bulletin No. 140, Biological Series No. 47. National Museum of Canada, Ottawa, Ontario. 619 pages.

Sealy, S. G. 1988. Aggressiveness in migrating Cape May Warblers: defense of an aquatic food source. Condor 90: 271-274.

Sealy, S. G. 1989. Defense of nectar resources by migrating Cape May Warblers. Journal of Field Ornithology 60: 8993.

Shackelford, C. E., and J. K. Shackelford. 2001. Rubycrowned Kinglet impaled on greenbriar thorn. Southwestern Naturalist 46: 116-118.

Sherick, R. 1966. The stuck duck. Blue Jay 24: 143.

Stegeman, L. C. 1953. Burdock and bird. Nature Magazine (American Nature Association, Washington D.C.) 46: 192.

Stensaas, M. 1989. Warbler entangled in burdock. Loon 61: 49.

Swanson, D. L., J. L. Ingold, and G. E. Wallace. 2008. Rubycrowned Kinglet (Regulus calendula). Revised. No. 119 in The Birds of North America. Edited by A. Poole. Cornell Lab of Ornithology, Ithaca, New York. http://bna.birds .cornell.edu/bna/species/119. (Accessed October 2012).

Swanson, D. L., J. L. Ingold, and R. Galati. 2012. Golden-crowned Kinglet (Regulus satrapa). Revised. No. 301 
in The Birds of North America. Edited by A. Poole. Cornell Lab of Ornithology, Ithaca, New York. http://bna.birds .cornell.edu/bna/species/301. (Accessed October 2012).

Tarof, S., and J. V. Briskie. 2008. Least Flycatcher (Empidonax minimus). Revised. No. 99 in The Birds of North America. Edited by A. Poole. Cornell Laboratory of Ornithology, Ithaca, New York. http://bna.birds.cornell.edu .bnaproxy.birds.cornell.edu//bna/species/099. (Accessed November 2012).

Taylor, P., B. Carey, W. Christianson, C. E. Curtis, L. de March, G. E. Holland, R. F. Koes, R. W. Nero, R. J. Parsons, M. Waldron, and G. Walz. 2003. The Birds of Manitoba. Manitoba Naturalists Society, Winnipeg, Manitoba. 504 pages.
Terres, J. K. 1980. Audubon Society Encyclopedia of North American Birds. Wings Books, New York, New York. 1109 pages.

Underwood, T. J., and R. M. Underwood. 2001. Observations on burdock-killed birds in King's Park, Winnipeg, Manitoba. Blue Jay 59: 64-69.

Underwood, T. J., and R. M. Underwood. 2013. Tufted Titmouse entangled in the burrs of Beggar's Lice (Hackelia virginiana). Northeastern Naturalist 20: 372-374.

Zimmer, S. J., and H. A. Kantrud. 1987. Burdock traps kinglet. Prairie Naturalist 19: 259-260.

Received 13 March 2013

Accepted 16 May 2013 


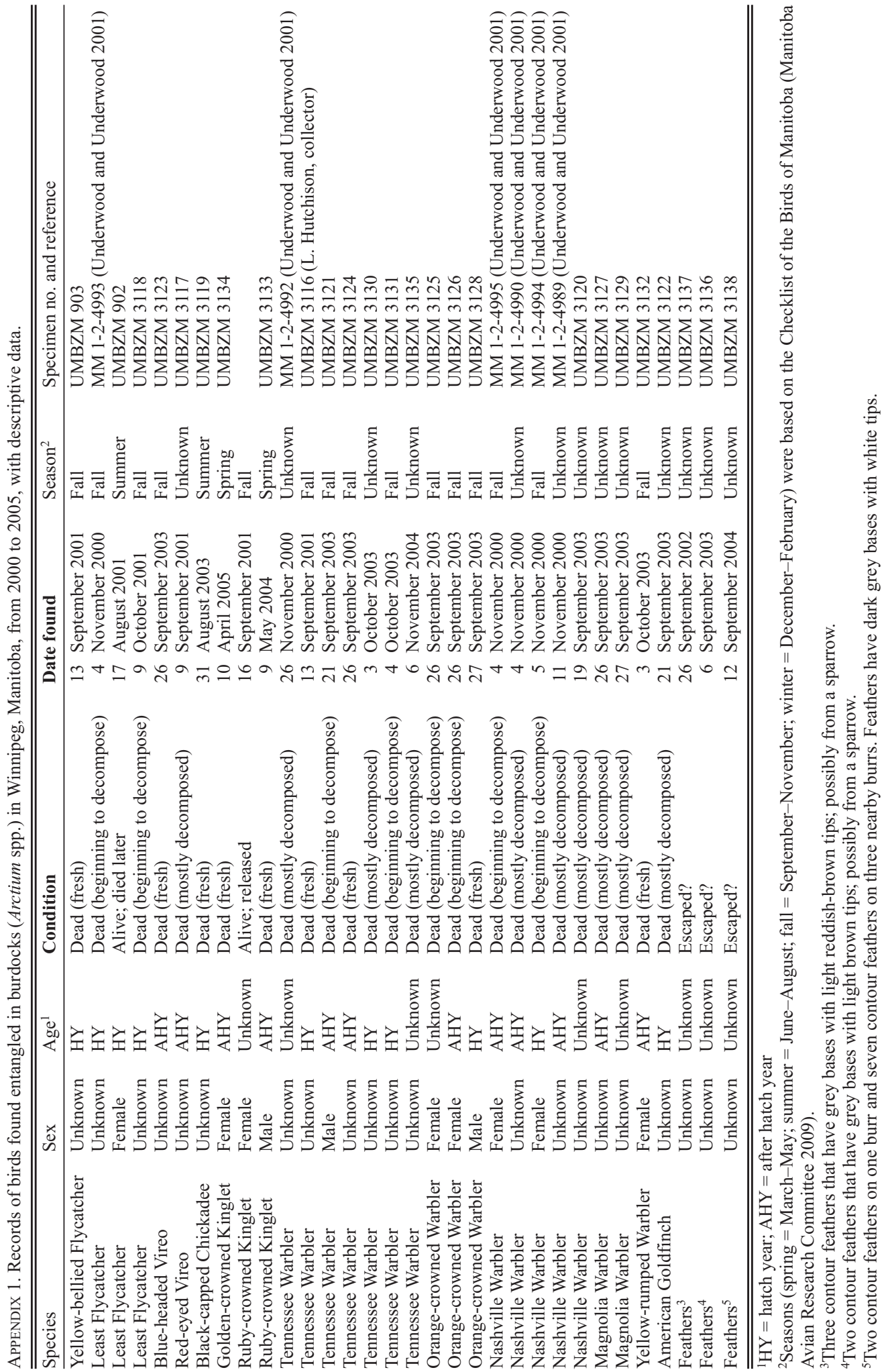

